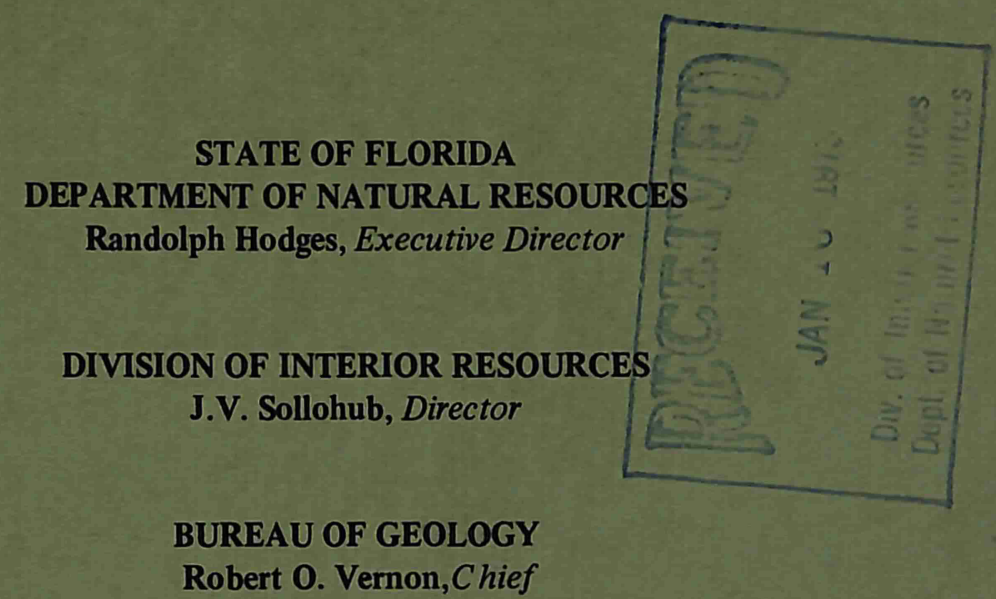

Information Circular No. 72

\title{
LAND USE CONFLICTS AND PHOSPHATE MINING IN FLORIDA
}

\author{
By \\ John W. Sweeney \\ Published by \\ BUREAU OF GEOLOGY \\ DIVISION OF INTERIOR RESOURCES \\ FLORIDA DEPARTMENT OF NATURAL RESOURCES \\ in cooperation with \\ UNITED STATES DEPARTMENT OF THE INTERIOR \\ BUREAU OF MINES
}

TALLAHASSEE

1971 


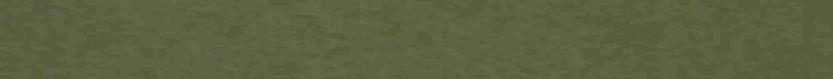

7.

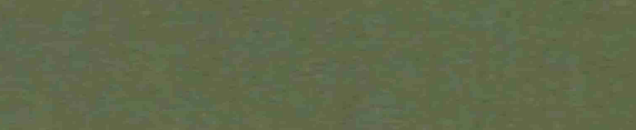

(1) 


\title{
STATE OF FLORIDA DEPARTMENT OF NATURAL RESOURCES \\ Randolph Hodges, Executive Director
}

\section{DIVISION OF INTERIOR RESOURCES}

J.V. Sollohub, Director

\author{
BUREAU OF GEOLOGY \\ Robert O. Vernon, Chief
}

Information Circular No. 72

\section{LAND USE CONFLICTS AND \\ PHOSPHATE MINING IN FLORIDA}

\author{
By \\ John W. Sweeney \\ Published by \\ BUREAU OF GEOLOGY \\ DIVISION OF INTERIOR RESOURCES \\ FLORIDA DEPARTMENT OF NATURAL RESOURCES \\ in cooperation with \\ UNITED STATES DEPARTMENT OF THE INTERIOR \\ BUREAU OF MINES
}

TALLAHASSEE

1971 
Completed manuscript received

May 21, 1971

Printed by the

Florida Department of Natural Resources

Divison of Interior Resources

Bureau of Geology

Tallahassee 


\section{CONTENTS}

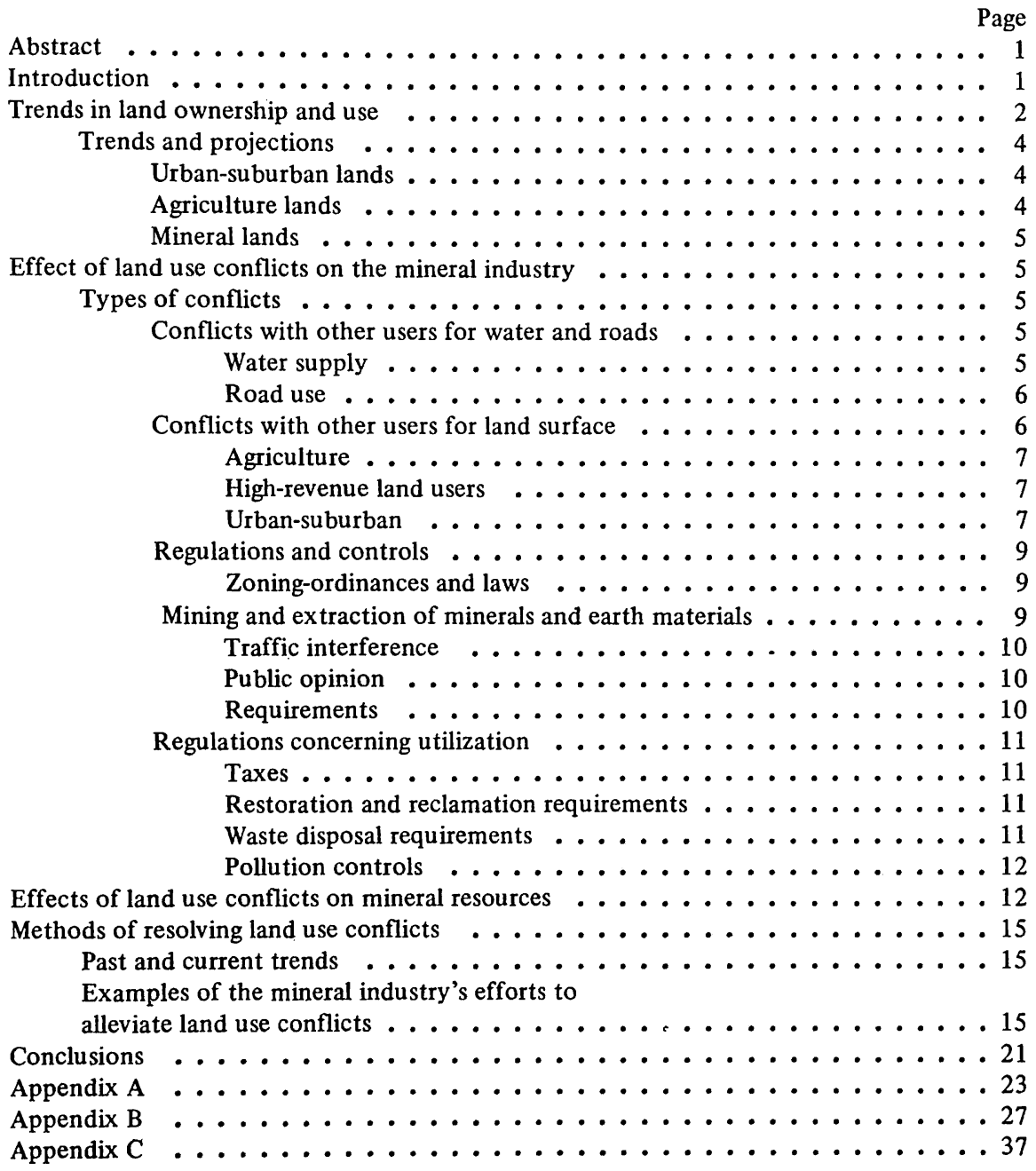




\section{ILLUSTRATIONS}

Fig. Page

1 General ownership map showing relationship of phosphate industry's holdings to the urban areas in the district .................. 3

2 Land containing phosphate rock lost due to interstate highway system taking the

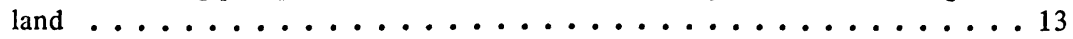

3 County road mined, relocated, reclaimed and paved ........... 14

4 Aerial photo of phosphate mine in the Florida phosphate field . . . . . . . 17

5 Photo of same area as in figure 4 , after reclamation ............ 18

6 Strip of land mined and reclaimed adjacent to a U.S. highway . . . . . . 20

TABLES

1 Agricultural land use, projection $\ldots \ldots \ldots \ldots \ldots \ldots \ldots$

2 Land mined and reclaimed $\ldots \ldots \ldots \ldots \ldots$ 


\title{
LAND USE CONFLICTS AND PHOSPHATE MINING IN FLORIDA
}

\author{
by \\ John W. Sweeney ${ }^{1}$
}

\begin{abstract}
As part of a national study, the Bureau of Mines examined the Florida land-pebble phosphate mining industry of Central Florida to jdentify trends in land use, conflicts in land use, and the effect of the conflicts on mineral resources.

Many conflicts exist in the study area, such as conflicts with other users of land resources and land surface, conflict with high-revenue land users, conflicts for land surface in urban and suburban areas, and conflicting restrictions concerning utilization. Projections are made showing that lands in phosphate company ownership are expected to be made available to help meet the need for future urban expansion in the study area.

Some phosphate resources have been lost due to land use conflicts; however, most of the resource loss has been small. Land use conflicts and phosphate mining are reconcilable, and considerable progress toward the maximum and multiple use of land and mineral resources can be made through farsighted planning based on factual data.
\end{abstract}

\section{INTRODUCTION}

The Bureau of Mines initiated a study in fiscal year 1967 on national mineral resources and land use conflicts. The purposes of the study were: (1) To show the effects of mineral extraction on land and community values; (2) to show the effects of land rehabilitation on end use following exploration, development, mining and processing of mineral raw materials; (3) to study the beneficial as well as detrimental effects of mineral industry activities on land; and (4) to point out the importance of the mineral industry's role in the national economy. As a segment of the national study, the Florida land-pebble phosphate district was examined.

1 Bureau of Mines, U.S. Department of the Interior, Liaison Officer-Florida 
The Florida land-pebble phosphate district produced about 79 percent of the total United States marketable production of phosphate rock in 1969; in 1968 this 'same district produced about 35 percent of the world production of marketable phosphate rock. During the past 15 years the use of fertilizer has almost tripled, and projections indicate that it will continue to grow but at a less accelerated rate.

The area of study is the Florida land-pebble phosphate district comprising about 2,000 square miles in Polk, Hillsborough, Manatee and Hardee Counties, Florida, as shown in figure 1. Of this area about 520 square miles, or 26 percent, is controlled by the phosphate industry. The five major cities in the study area are almost completely surrounded by phosphate industry holdings, making the phosphate industry an important controlling factor in the future use of adjacent land. The population within the study area (1970) is about 750,000 and is projected to be over 900,000 by 1975 , a 21 -percent increase; about 60 percent of the people live in urban portions of the study area, demonstrating that additional land will be needed for future expansion. The portion of the study area not owned by the phosphate industry is mainly in private ownership and is used for agricultural purposes. An estimated 200 square miles of this area is classified as urban and surburban land.

There are many land use conflicts in this section of Florida; the population of rural areas and cities is growing rapidly, and the need for land for both urban and suburban development is increasing. The phosphate industry in Florida is trying to meet the ever-growing world demand for phosphate in a world undergoing a population explosion.

\section{TRENDS IN LAND OWNERSHIP AND USE}

In 1963-64, the Water Resources Committee of the Florida Phosphate Council assembled data supplied by phosphate companies and projected land use for the years 1980 and 2015. However, the companies did not give complete use patterns on all land under their ownership; the data reflect use patterns on about two-thirds of the land under their control in 1964. Additional phosphate lands have been purchased by the established companies and by new companies developing reserves in the area since this study was completed. The use patterns on these new reserve lands are not available. The data included, however, demonstrate generally the intended future use of phosphate lands. Trends and projections on these various land uses are discussed as follows. 


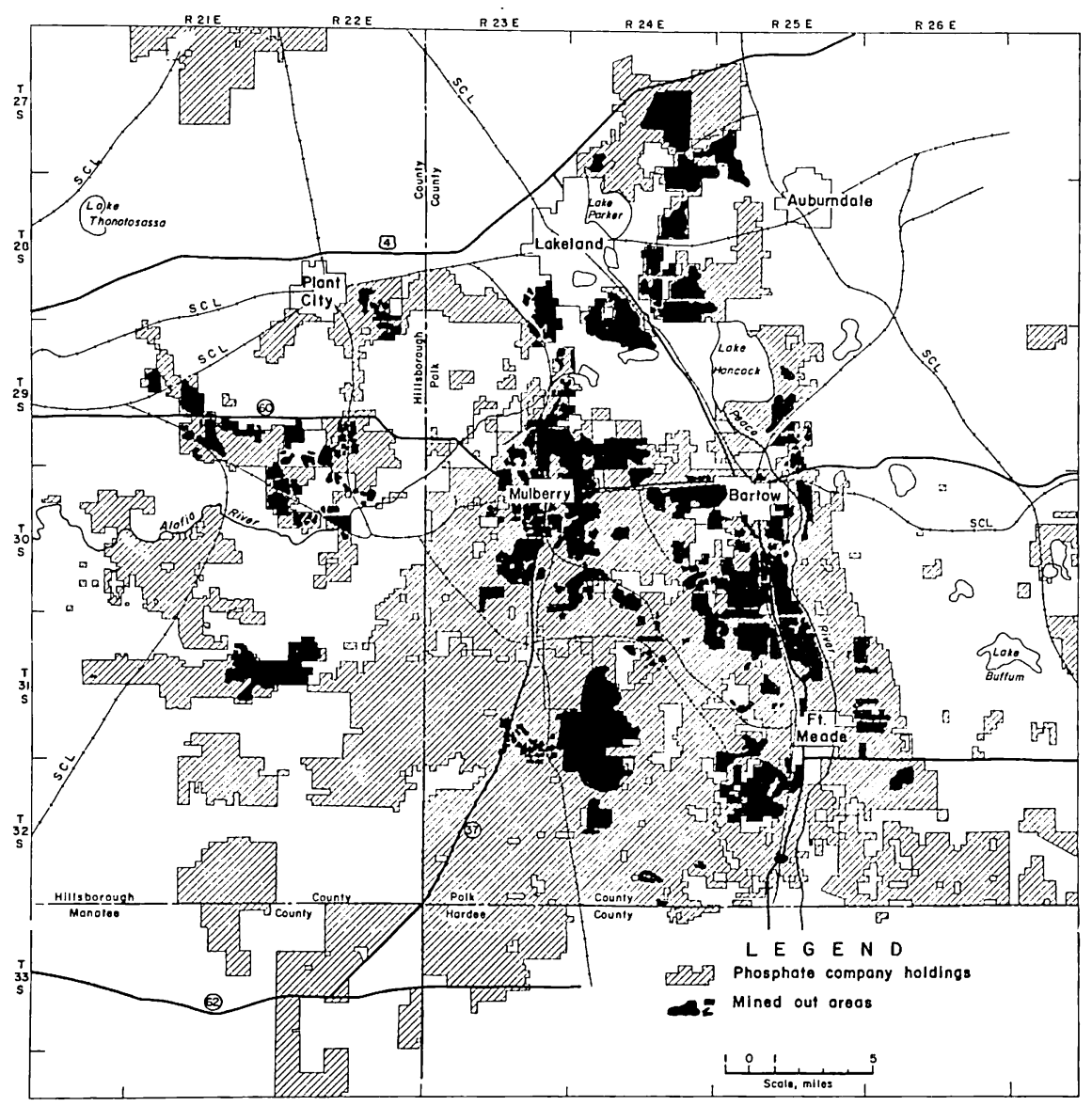

Figure 1. General Ownership Map showing Relationship of Phosphate Industry's Holdings to the Urban Areas in the District (1967). 


\section{TRENDS AND PROJECTIONS}

\section{URBAN-SUBURBAN LANDS}

There is a need for more land in the study area for urban-suburban, residential, commercial and industrial use. Until recently, the cities had enough land expansion, but they have now almost reached a saturation point and additional land for residential and industrial growth is needed. The phosphate industry is in a position to make land available, and present and projected trends in land use depends on cooperation by the phosphate industry, since it holds the key for future urban expansion. The industry believes there can be compatible development between urban areas and industry; they have pledged to try to make lands available to the cities. However, dependency of some of the urban areas on the phosphate industry could retard growth rates, because they may not be able to expand as fast as may be otherwise warranted.

Projected land use data furnished by the industry indicate that by 1980 it will have made available about 4,200 acres for residential use, and by 2015 there will be a total of 9,000 acres made available. These lands will probably be utilized to meet the growing needs of the communities. By 1980 there will be over 3,000 acres available for commercial use and over 2,000 acres for industrial use; in 2015 , projections indicate that there will be about 5,000 acres available for commercial use and about 5,000 acres for industrial use. Since many of the contributing companies did not provide land use information on all of their lands and land acquisition is currently in progress (1967), the figures cited should be considered to be on the conservative side.

\section{AGRICULTURE LANDS}

A major portion of the economic base of the study area is the agriculture industry, including citrus groves, cattle, and truck farming. The phosphate and agricultural industries exist together with very few major conflicts. Agricultural land is purchased for phosphate reserves, but the agricultural use usually continues until mining takes place. In many cases these reserve lands are leased back to the seller, who continues the same agricultural pursuits as he did before the land was sold. After mining and reclamation, the land can again be used for agriculture, in many cases for higher agricultural uses because of improvements. An illustration would be unimproved pasture land before mining that becomes improved truck farming or grove land after mining and reclamation. This trend probably will continue as it has in the past, and the phosphate industry will actively use these reserve lands for agricultural purposes. 
Projected land use data furnished by the phosphate industry show the agricultural uses of phosphate land for 1980 and 2015 (Table 1):

\section{TABLE 1.-AGRICULTURAL LAND USE PROJECTION (acres)}

\begin{tabular}{lrllll} 
Year & Citrus & Forest & $\begin{array}{l}\text { Pasture } \\
\text { (Unimproved) }\end{array}$ & $\begin{array}{l}\text { Pasture } \\
\text { (Improved) }\end{array}$ & $\underline{\text { Crops }}$ \\
\hline 2015 & 18,000 & 62,000 & 47,000 & 23,000 & 13,000 \\
1980 & 7,000 & 55,000 & 46,000 & 11,000 & 6,000
\end{tabular}

These projections were determined by using 1964 phosphate company land holdings and should be considered conservative estimates; they indicate that the trend is to higher agricultural uses.

\section{MINERAL LANDS}

The phosphate industry maintains mineral exploration programs to improve their reserve position, and exploration has moved southward into Manatee and Hardee Counties where both established and new companies have purchased phosphate reserve lands. High-grade deposits in the northern part of the district in Polk and Hillsborough Counties are being depleted, and mining will eventually move southward to southern Polk, Manatee, and Hardee Counties where lower grade deposits are available.

The phosphate industry states that it will possibly reclaim about 80 percent of the land mined in the future; this is about the maximum possible since the remaining acreage is required for waste disposal. This reclaimed land could then be made available for residential, industrial, or agricultural uses. The phosphate industry controlled about 520 square miles in 1967; through 1965, about 80,000 acres or 125 square miles, had been mined and about 10,000 acres had been reclaimed. Data on land reclamation since 1965 are not available, but less land probably was reclaimed in 1966-70 than in 1960-65 because of austerity programs initiated by most of the phosphate companies.

\section{EFFECT OF LAND USE CONFLICTS ON THE MINERAL INDUSTRY}

TYPES OF CONFLICTS

\section{CONFLICTS WITH OTHER USERS FOR WATER AND ROADS}

WATER SUPPLY

The four large users of water in the study area are the phosphate industry, citrus industry, food packing companies, and municipalities. Under normal conditions, water is in abundant supply; however, under drought conditions, 
charges have been made that the phosphate industry lowered the water table. During these drought conditions, citrus growers also require great volumes of water. Projected water needs in the Southwest Florida Basin are adequate through the year 2015. However, it is anticipated that soon after 1980, some of the subbasins that are more industrialized and which have expanding urban populations will have water shortages. Water will then have to be diverted from subbasins with abundant water supply to the areas in need. ${ }^{2}$

\section{ROAD USE}

There is no conflict in use of the roads in the area, but competition does exist for the subsurface where phosphate deposits may exist under rights-of-way. It would be impossible to mine under existing Federal and State roads; however, it has been done under county roads.

\section{CONFLICTS WITH OTHER USERS FOR LAND SURFACE}

There is a conflict in the study area for the land surface, and it has become more acute in recent years. The phosphate industry started mining in Florida in the late 1880's; many small companies were formed and land acquisition of the known high-grade deposits was active. By the 1930's much of the reserve lands that are owned today had been acquired by the phosphate companies. In the early years of the industry, very little of the land purchased by the companies was used for purposes other than mining. The land usually stayed in its purchased state until mined and was not reclaimed after mining.

The phosphate companies' land holdings became large and the industry experienced a rapid growth, contributing to the expansion of cities and towns in the area. Lands adjacent to present cities are now owned by the phosphate industry. The rapid urbanization of the study area within the past decade has made the use of land for mining and water conservation a matter of concern to the public as well as the industry. The influx of population has created a need for land not only for housing and industry, but also to replace land removed from agricultural and recreational uses by urbanization and mining activities.

Conflicts for land surface have arisen between the phosphate industry and the petroleum industry, which has leased large acreages of land for oil exploration. By acquiring mineral rights to these lands, the petroleum industry retards the phosphate industry's acquisition of reserve lands in the same area.

${ }^{2}$ Florida Board of Conservation, Division of Water Resources. Florida Land and Water Resources, Southwest Florida. 1966, 181 pp. 


\section{AGRICULTURE}

Phosphate mining operations have had past and could have future adverse and limiting effects upon agricultural production in the study area. Croplands are lost through phosphate industry expansion, reducing the importance of the productive agricultural segment of the regional economic base, since the price paid for phosphate reserve lands greatly exceeds the price for agricultural lands. The land may still be used for agricultural purposes before mining, but mining is considered the highest priority use. After mining and reclamation, some of these lands can again be placed into citrus groves or other agricultural production.

\section{HIGH-REVENUE LAND USERS}

There is a conflict between the phosphate industry and high-revenue land users in the study area. For example, if a certain parcel of land was being considered for purchase by both a phosphate company and a light industrial concern, the phosphate company might be willing to pay more for it than the high-revenue land user because it would be purchasing the mineral reserves in addition to the land surface. If the phosphate company was successful in obtaining the land, this would restrict its use to mining, and to agricultural uses before mining, and could retard the potential of attracting various types of the manufacturing industry to the area.

\section{URBAN-SUBURBAN}

A major conflict in the study area arises from the need for additional urban-suburban land. The problem has been especially acute in the cities of Bartow, Lakeland, and Mulberry, Polk County, which are virtually surrounded by phosphate industry land holdings. In the last 10 years, the population of each city has grown by 30 percent or more, and each needs more land for residential, industrial, and commercial uses.

Lakeland has undergone rapid growth; in 1960 the population of the metropolitan area was about 61,000 , and it is forecast that by 1975 it will be 88,000 , an increase of 44 percent. This forecast reflects a declining rate of increase in population within Lakeland, consistent with the limited land available. In the corporate limits of the city, the population is expected to increase from 44,000 in 1964 to only 47,000 in 1975 . The forecast shows most of the increase to be in the urban fringe. ${ }^{3}$

3 City of Lakeland, Planning and Zoning Board. Economics, Population, Land Use, Lakeland, Florida 1964-1975. 1964, 25 pp. 
The citrus and phosphate mining industries are the major users of land in the 175-square-mile Lakeland Planning Area; approximately 126 square miles are in the nonurban use. ${ }^{4}$ There is an acute shortage of available land within the corporate limits of Lakeland. Large areas of land near the city have already been mined, and phosphate companies own large tracts of land to the northeast, east, and southwest. Phosphate lands, mined and unmined, constitute approximately 35 square miles in the Lakeland Planning Area; much of this land is adjacent to the present corporate limits of Lakeland.

Phosphate property will not be available for development as residential, manufacturing, or industrial park use until after mining and reclamation. Until recently, mining usually rendered the land unsuitable for many other uses; but since 1961, the phosphate mining companies have been operating under a voluntary policy to reclaim the mined-out land to "help meet the aesthetic and practical needs of the community," as stated by the industry's Florida Phosphate Council.

Reclaimed land in the Lakeland metropolitan area has been used for citrus groves, residential and commercial building sites, agriculture, parks, and school sites. These reclaimed lands will be used in the future as improved natural lands.

Other lands adjacent to the city are marginal and are either used for citrus or unavailable for use, such as swamps or lakes; all of these land uses combine to curtail the expansion of the city of Lakeland.

Other cities in the study area have similar urban and suburban conflicts. Bartow, Mulberry, and Fort Meade, Polk County, are surrounded by phosphate company lands, and urban and suburban expansion is seriously curtailed. A need exists for land within the corporate limits of Bartow and Mulberry, since almost all available lands are presently being used, and growth is being curtailed. A serious conflict is not expected to arise in Fort Meade because of its slower growth rate, and adequate land is available for use within its corporate limits. A conflict also exists in Plant City, Hillsborough County, because of the large tracts adjacent to the city owned by phosphate companies.

4 Work cited in footnote 3. 


\section{REGULATIONS AND CONTROLS}

\section{ZONING - ORDINANCES AND LAWS}

Hillsborough, Manatee, and Sarasota counties have zoning ordinances regulating mining. In 1965, a preliminary comprehensive zoning plan was introduced for Polk County; a referendum to adopt the plan was defeated. In 1970, Polk County passed an ordinance regulating the use of land outside the incorporated cities in Polk County. The ordinance requires the phosphate mining companies to submit a mine site plan and to reclaim all surface areas actually mined or disturbed. Hillsborough County does not have a specific zoning designation for mining. The mining classification is included in the three agricultural zones: (1) A - agriculture which includes feed lots, sawmills, trailer parks and so forth; (2) A-A in which there must be a minimum of one acre for any use; and (3) A-R agriculture-residential. The zoning regulations related to mining for Hillsborough County are as follows:

\section{MINING AND EXTRACTION OF MINERALS AND EARTH MATERIALS}

1. Use to be added to the A and A-A Zoning Districts of the Hillsborough County Zoning Regulations;

a. Extraction of minerals; extraction of earth materials for sale or use off the premises, subject to approval by the County Engineer following his finding that the proposed extraction operation will not adversely affect surface drainage within the area or otherwise impair the public safety, health, or general welfare of adjacent residents or property. County Engineer approval will not apply where excavation takes place solely for drainage purposes or other land improvements upon the premises in question.

2. Use to be added to the A-R Zoning District within the Hillsborough County Zoning Regulations:

Extraction of minerals; extraction of earth materials for use elsewhere, subject to the following conditions:

a. No such extractions shall be permitted within 100 feet of a park boundary, within 200 feet of the centerline of a primary or secondary state road, or 150 feet of the centerline of any other public street or road, within 500 feet of an adjacent R-1, $\mathrm{R}-2, \mathrm{R}-3$, District or a recorded residential subdivision within the A-R District or within 100 feet of the boundary line of an existing public right-of-way or public easement for drainage or utility purposes.

b. Approval by the County Engineer following his finding that the proposed extraction operations will not adversely affect surface drainage within the area or otherwise impair the public safety, health, or general welfare of adjacent residents or property.

c. Filing of a reclamation plan for uses approved within the A-R classification for the review and approval of the Zoning Director and the Hillsborough County Planning Commission.

The above requiretients will not apply where excavation takes place solely for drainage purposes or other länd improvement upon the premises in question. 
Although mining is permitted in Hillsborough County in the agricultural zones without any permit, a special permit is required to build a phosphate washer, chemical plant, or other structure exceeding building requirements in these zoned areas. Manatee County adopted an amendment in 1966 to their zoning ordinance to regulate all mining operations in the county. This amendment constitutes a complete program for mining, including posting of bonds for reclamation of mined lands. Sarasota County adopted a resolution in 1965 to regulate the mining of phosphate and other minerals in the county. Lakeland, Bartow, Mulberry, Fort Meade, and Plant City do not permit mining within their respective cities. Mining could be allowed; however, by passage of a special ordinance. (See Appendix A.)

\section{TRAFFIC INTERFERENCE}

A rail-highway traffic conflict formerly existed in the Tampa area where shipments of processed phosphates were moved by rail to loading terminals. All shipments moved through the city to the ports, creating rail and traffic congestion at times. The construction of the East Bay complex at Rockport on the east side of Hillsborough Bay has mainly eliminated this conflict, and at other terminals phosphate is shipped with no apparent conflicts.

\section{PUBLIC OPINION}

Adverse public opinion caused one phosphate company to relocate a proposed new chemical plant. The site picked by the company and the pollution control equipment scheduled to be used were approved by the Florida Department of Air and Water Pollution Control; however, adverse public reaction caused by the possibility of air pollution under abnormal operating conditions forced the company to relocate in another county. Adverse public opinion also caused a phosphate company not to mine a lake adjacent to a city in the area rather than create ill will.

\section{REQUIREMENTS}

The Southwest Florida Water Management District requires all phosphate mining companies to submit a mining plan whenever mining would affect drainage in the Southwest Florida Basin. All streams in the basin are considered a part of the district, and the Southwest Florida Water Management District has jurisdiction over them.

The Florida Department of Air and Water Pollution Control requires all operations that may be a source of air or water pollution to obtain a permit for the operation, construction, or expansion of any such facility. Those engaged in operations which may result in pollution are required to file reports which contain information relating to location, period of emissions and composition, and concentration of effluent. 


\section{REGULATIONS CONCERNING UTILIZATION}

TAXES

Agricultural lands in the study area are valued from $\$ 100$ to $\$ 300$ per acre. The ad valorem tax on these lands when used for agricultural purposes is about $\$ 100$ per acre; the millage rate ranges from 17.5 mills to 50 mills per dollar assessed. When these agricultural lands are purchased by a phosphate company, the ad valorem tax is based on the potential worth of the land rather than the agricultural assessment even though the land still may be used for the same agricultural purposes in the interim period before mining. The amount paid by phosphate companies for agricultural land will range from $\$ 400$ to $\$ 640$ per acre.

\section{RESTORATION AND RECLAMATION REQUIREMENTS}

Legislation on the State level has been proposed that would require the industry to reclaim mined lands. In 1970, Polk County passed an ordinance requiring the phosphate industry to reclaim all surface areas actually mined or disturbed. Manatee County has an ordinance requiring phosphate companies to reclaim mineral land.

Sarasota County has adopted a regulation requiring any mining company to reclaim mined-out lands following a specified resolution. Bartow has a resolution in their city code stating if and when permission is granted for mining within the city, restoration of the land must meet certain requirements and be completed before a specified date. (See Appendix B.)

\section{WASTE DISPOSAL REQUIREMENTS}

A Governor's Committee was formed in 1960 to study the problem of breaks in phosphate slime pond dams. The committee consisted of the State Geologist, Florida Bureau of Geology; the Director of Sanitary Engineering, State Board of Health; the Director, Florida Bureau of Water Resources, Department of Natural Resources; and a phosphate committee consisting of one representative from each of the eight active phosphate mining companies in the State. The phosphate industry committee recommended a minimum design to be used in construction of slime settling dams. The Governor's Committee recommended that the phosphate companies' minimum specifications be adopted. ${ }^{5}$

5 State of Florida, State Board of Conservation, Division of Geology, Florida Geological Survey, Fourteenth Biennial Report 1959-1960, 1961, pp. 67-80. 
The Florida Department of Air and Water Pollution Control has set minimum requirements for the construction of earthen dams at phosphate mining operations to try to eliminate or reduce dam failures.

\section{POLLUTION CONTROLS}

Air and water pollution in the phosphate industry is regulated and enforced by the Florida Department of Air and Water Pollution Control. The department samples air and water in the district to see that pollutants do not exceed State standards.

Construction of new plants is regulated by a permit system which allows only a given number of plants to put effluents into the air in a given area, thus keeping pollution at a minimum. Sarasota County has a code on air and water pollution which gives the county enforcement power along with the State.

\section{EFFECTS OF LAND USE CONFLICTS ON MINERAL RESOURCES}

There have been two instances in the study area where lands with phosphate values have been lost. One phosphate company lost a strip of land approximately 300 feet wide by 2 miles long ( 36 acres), because it was taken for use in the Interstate Highway System. The company was compensated, but the contained mineral -- 275,000 tons of phosphate rock -- under this land was lost, shown in figure 2 .

Another phosphate company lost 38 acres of phosphate reserves land due to relocation and four-laning of a State highway. Phosphate occurrences are found under many county roads in the study area, and unless permission can be obtained from the proper authority, phosphate reserves underlying these rights-of-way will be lost. Permission has been granted in some instances to mine these deposits; however, lengthy legal procedures are usually involved, figure 3.

Phosphate occurs under many lakes in the study area. Attempts have been made to obtain legal permission from the authority involved to mine under certain lakes; permission was denied and the mineral was lost.

The Federal Government holds the mineral rights to several 40-acre tracts of land scattered among the phosphate companies' land holdings. In some cases the companies have had to mine around these small tracts because they were not able to obtain mineral rights. Since the companies own the surface rights and have not been able to obtain mineral rights, there have been instances where these Government lands have been used as waste disposal areas, making it exceedingly difficult, if not impossible, to ever recover the mineral values. 


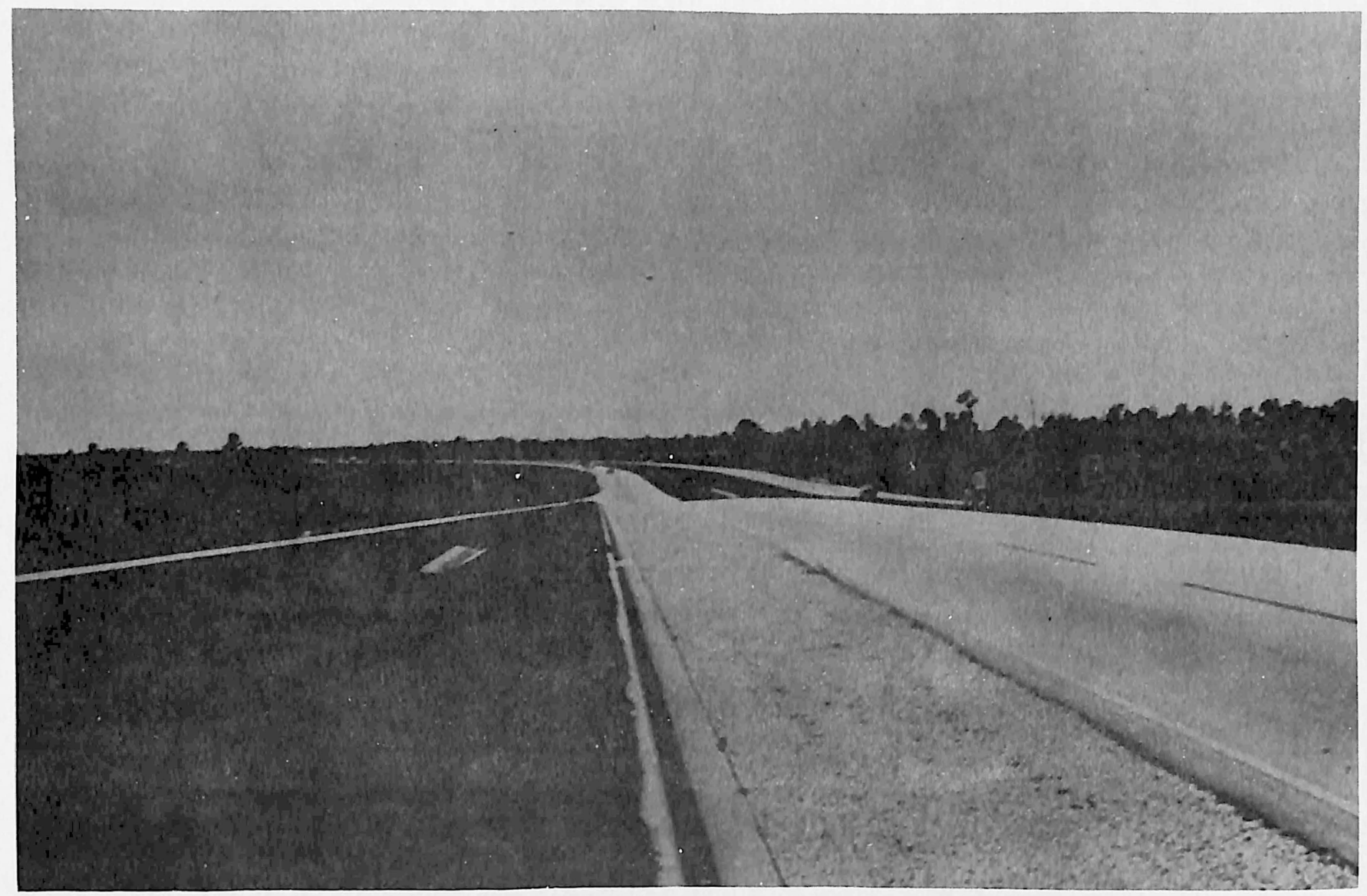

Figure 2. Land Containing Phosphate Rock lost Due to Interstate Highway System Taking the Land. 


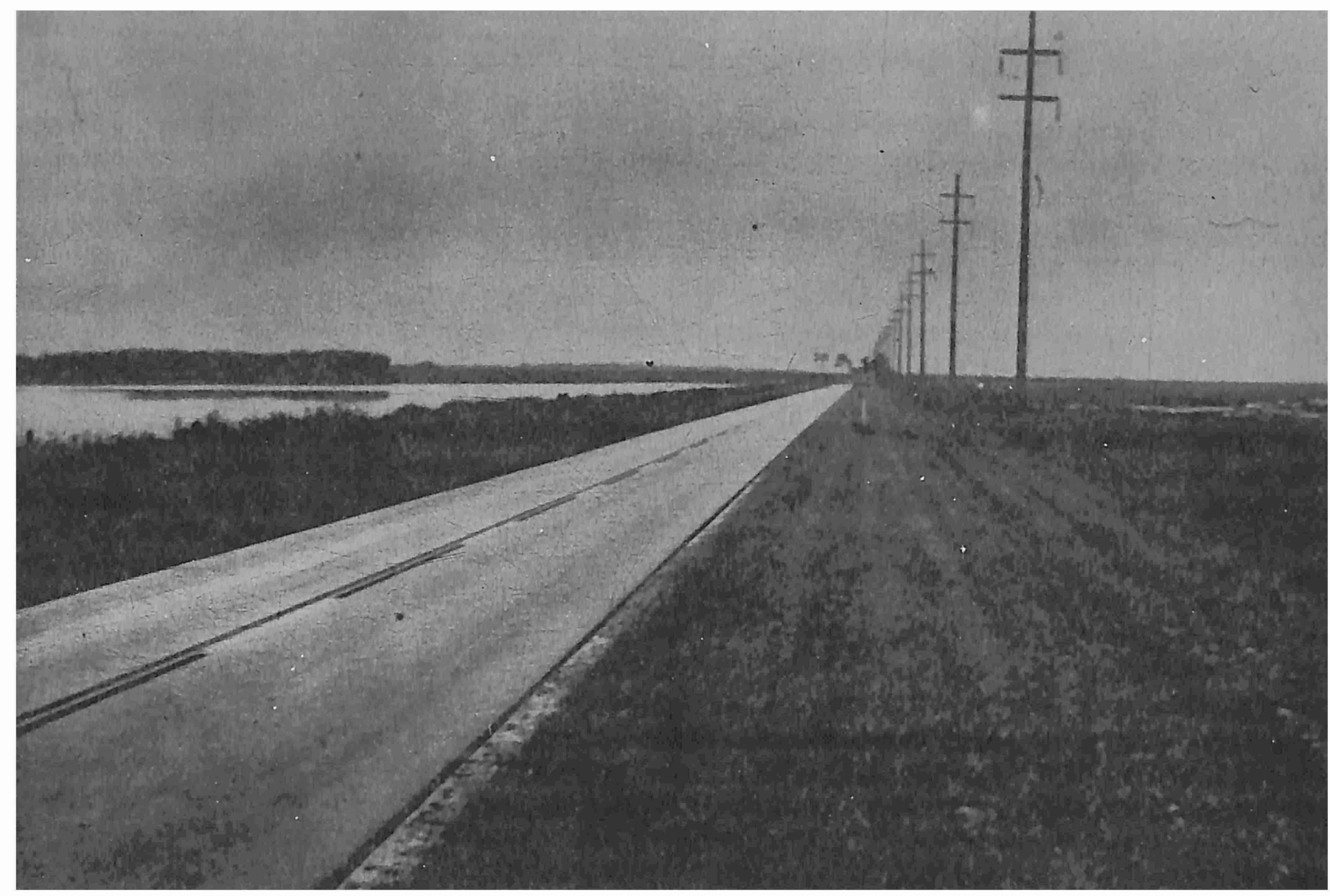


Phosphate probably occurs under most of the cities in the area. These lands are being put to their most valuable present use; therefore, the mineral deposits under them will be lost. However, in a few instances lands within the city limits of Bartow have been mined and reclaimed. These lands were in swampy areas and unsuitable for other purposes in their original form. After mining and reclamation, the lands were made available for other uses. Appendix $\mathrm{C}$ shows the document granting permission to mine within the city of Bartow.

It has been projected ${ }^{6}$ that there will be a water shortage after 1980 in some of the more industrialized basins. A water shortage in the study area could hamper future phosphate production. Mineral values would not be lost, but a serious conflict could arise with other users of water, hampering mineral production.

\section{METHODS OF RESOLVING LAND USE CONFLICTS}

\section{PAST AND CURRENT TRENDS}

The Florida Phosphate Council is the voice of the phosphate industry; it advertises and publishes to inform the public on the activities of the industry. The Council is made up of members of the eight active mining companies and three chemical fertilizer processors who serve on the following standing committees: Waste Control, Technical Sub-Committee on Effluent Control, Land Use and Reclamation, Water Resources, Public Relations, Legislative, and Taxation and Zoning Sub-Committee. The Council established these committees to promote and coordinate activities; each member company has assigned to membership the individual of their operating staff responsible for managing that phase of their respective programs. The various committees of the Council, in order to gain acceptance from the public, meet with State, county, and city level governments to discuss the various problems facing the industry and the communities. There are several other planning groups on the State and county level. Most of the planning groups on the State level are concerned with water resources and recreation and make little mention of the mining industry.

\section{EXAMPLES OF THE MINERAL INDUSTRY'S EFFORTS TO ALLEVIATE LAND USE CONFLICTS}

Probably the major effort of the phosphate industry to alleviate land use conflicts was to eliminate former practices that did not consider the public interest. The primary effort has been land reclamation activities. In the early years, very little land was reclaimed; in recent years, because of the growing need

\footnotetext{
6 Work cited in footnote 2 .
} 
for land, reclamation activities have been accelerated by an industry-wide pledge in 1961 that as much mined land as practicable would be restored to a useful condition. The industry undertook this land reclamation program to present a better public image, to gain public acceptance, and in some cases to realize a profit. While the economics of reclaiming mined-out phosphate land in remote areas are still none too promising, it is now considered good business, and good public relations, to restore as much mined-out land as possible.

The feasibility of reclaiming lands is usually determined by two factors. The first is location, because land in remote areas usually has no use which would justify costly reclamation. The second factor is the best use of lands to be reclaimed; if this use will not provide an adequate return, the high cost of reclamation cannot be justified.

The following table shows the land mined and reclaimed from 1961 through 1965 with projections for 1966-71. Factual data for 1966-70 are not available.

\begin{tabular}{lcc}
\multicolumn{2}{c}{ TABLE 2.-LAND MINED AND RECLAIMED } \\
(acres) \\
Year & Mined & \\
1961 & 2,435 & Reclaimed \\
1962 & 2,342 & 1,865 \\
1963 & 2,331 & 1,618 \\
1964 & 2,779 & 1,980 \\
1965 & 3,027 & 2,092 \\
& & 2,244 \\
Totals & 12,914 & \\
$1966-71$ (Projections) & 19,903 & 9,799 \\
& & 15,963
\end{tabular}

This record of reclamation shows the phosphate industry reclaimed 74 percent of acreage mined in 1965, and plans for the next five years indicate that 80 percent will be reclaimed. The ultimate aim of the various voluntary programs and activities is to promote goodwill and public acceptance. From 1961 through 1965, the phosphate industry donated 1,527 acres of land for recreational purposes, civic clubs, schools, wildlife sanctuaries, and other uses, shown in figures 4 and 5 .

The following are examples of steps the industry has taken to alleviate land use conflicts and problems.

A phosphate company completed mining and reclamation of about 1,200 acres ot the headwaters of the Alafia River and deeded the land to the Southwest Florida Water Management District for the creation of a water reservoir to be used for flood control, water conservation, and recreation. 


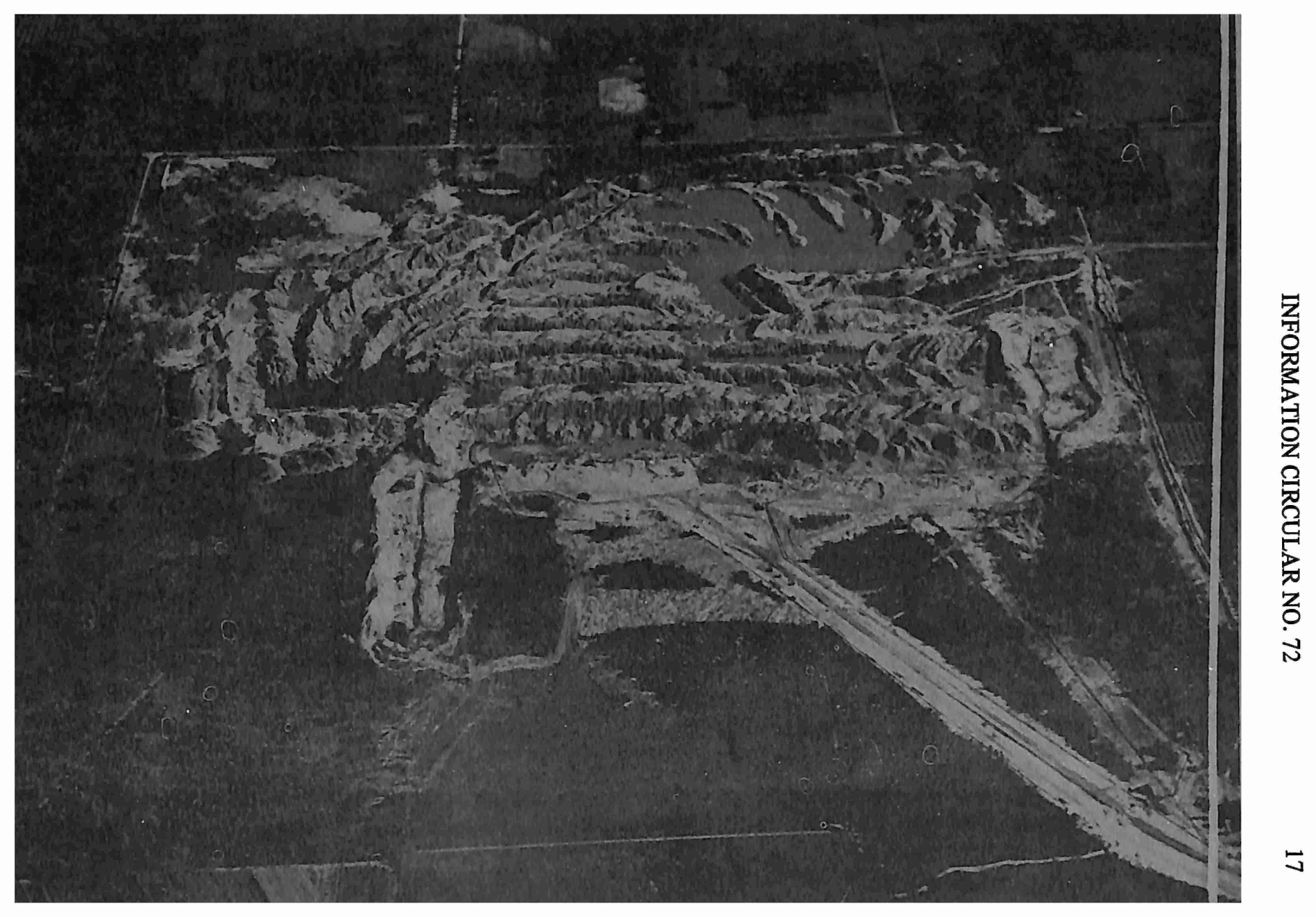

Figure 4. Aerial Photo of a Phosphate Mine in Florida Phosphate Field. 


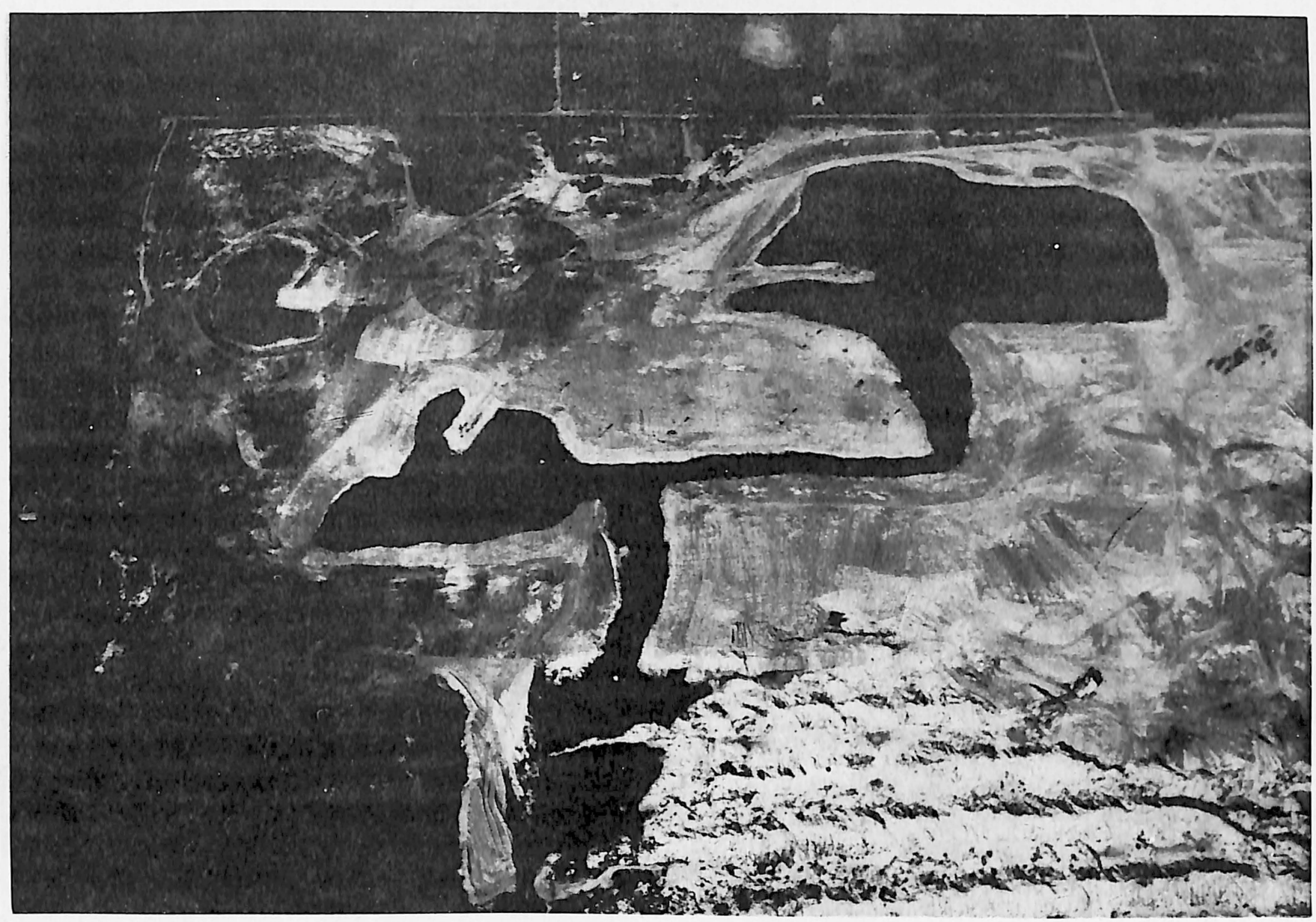


Some of the phosphate companies in the study area are following a program of simultaneous reclamation as mining progresses by placing overburden spoils to form land and lakes on a preplanned basis, thus making many acres available for residential and other uses sooner than if reclamation has been postponed until after mining.

All the phosphate companies have an active land management program to make sure their lands are being used in the most productive form. Reserve land is being used for agriculture, pasture, tree farms, and recreation. Mining for phosphate is the companies' highest use for the land; but after mining and reclamation, these lands can be used for citrus groves, residential, and industrial purposes. All land cannot be reclaimed immediately; large acreages are needed to store waste from processing. Although these lands will be out of active use for many years, they act as collecting basins for surface water used and reused in the processing of the phosphate, thereby lowering the demand for water pumped from deep wells. Two companies mined and reclaimed tracts of land within the city of Bartow. Before mining, most of the lands were unusable due to their swampy nature. After mining and reclamation, the lands are 100 percent usable and will probably be developed as residential areas.

Four companies have taken the initiative to reclaim lands adjacent to Lakeland, Bartow, and Mulberry for use by these cities for residential and/or industrial uses. The phosphate industry feels that there should be compatible development of the industry and community, and even though there are conflicting situations the companies want to make land available to cities as their needs for land grow.

Two companies have mined and reclaimed land adjacent to U.S. Highway 17 south of Bartow in anticipation of this highway being four-laned. The phosphate rock was recovered, and the area was left in condition for highway expansion. The phosphate rock in this area was not lost, and good road base remains, as shown in figure 6 .

A rather involved illustration of benefit derived from reclamation is industry's efforts to reduce the cost of citrus groveland so it can be purchased at more reasonable prices so the contained phosphate can be mined. Many of the companies have become involved in citrus growing on a large scale. More than 5,500 acres of citrus groves in the Polk-Hillsborough County area are owned by phosphate companies; much of this area is reclaimed land, and it is indicated that this type of land will be used extensively in the future for new groves. ${ }^{7}$

7 Citrus World. Phosphate Companies Important Factor in Citrus. Vol. 3, Issue 4, 1966, pp. 10-11. 


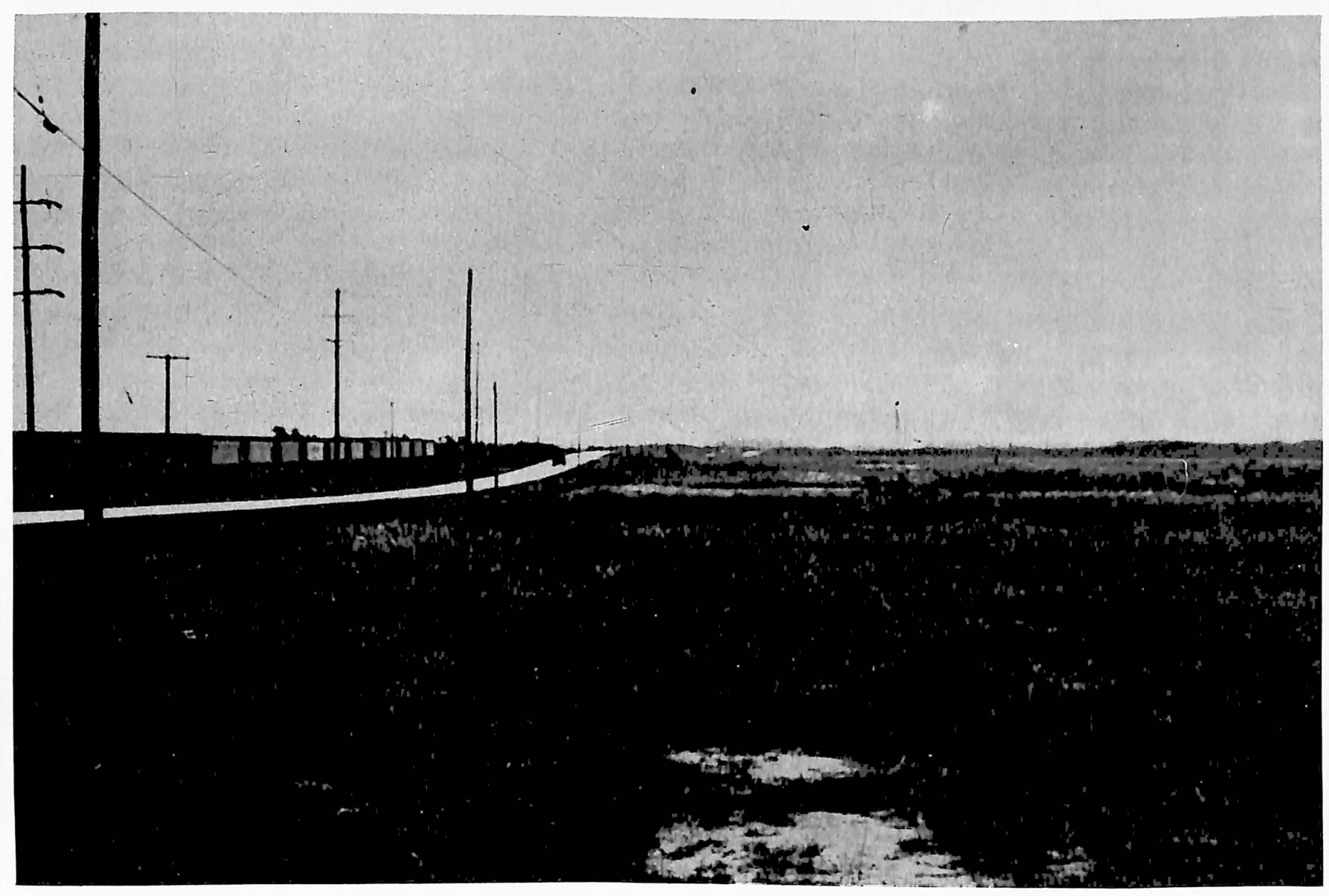

Figure 6. Strip of Land Mined and Reclaimed Adjacent to U.S. Highway. 
The reasons for the phosphate companies' venture into the citrus industry are two-fold: first, the profits from crops help the companies pay their taxes on their large land holdings; second, by planting citrus trees on reclaimed land they are demonstrating that these lands will grow citrus groves as well as natural lands. The price of grovelands is around $\$ 4,000$ per acre, too expensive in many instances for purchase by phospahte companies. Since the phosphate companies own citrus lands, they may be able to trade newer citrus groves on reclaimed land for older groves on phosphate reserve land. An arrangement may be worked out in this type of transaction to lower the cost of phosphate lands underlying citrus groves, thereby adding to the reserves in the area.

\section{CONCLUSIONS}

All catergories of conflicts exist in the study area, such as conflicts with users for land resources and land surface, conflicts with high-revenue land users, conflicts in urban and suburban areas, conflicts with various regulations and controls, and conflicting restrictions concerning utilization. The current situation should not be considered too serious as far as loss of mineral resources is concerned; most of the conflicts can be resolved. However, planning for the future is necessary to forestall serious conflicts which could cause loss of phosphate reserves. Serious conflicts could affect the production of the phosphate industry, which in turn could have a direct bearing on the local economy and affect the nation's fertilizer supply.

Mining has the least flexible land requirements of any of the major users of land. Agricultural, community, and industrial development can be accommodated in almost any area, but mining is naturally limited to the specific area in which the resource is found. In order to reserve phosphate land for future mining, the companies have had to either purchase or option extensive tracts of land. In the past, this meant taking the land out of active use; however, within the past decade all of the phosphate companies have practiced active land management programs on their properties. Since 1961, the industry has accelerated a program of land reclamation. The companies should be encouraged to make lands held in reserve available for other uses before mining and to reclaim previously mined lands in areas needed to expand.

The industry has worked closely with the city of Lakeland on reclamation of land adjacent to the urban area. If well planned, the reclamation program should be a major step in helping cities solve their land problems. Based on these reclamation plans, approximately 4,000 acres of phosphate land will be available for urban development or for open space by 1975 . About 1,400 acres will be available for residential use is almost one-fourth of the anticipated need for residential land from 1964 to 1975. 
Phosphate comparies are large consumers of water for use in transporting and processing phosphate rock, and they try to conserve and reuse as much of this water as they can. In many of the land management programs, timber is planted on reserve lands and spoil piles to reduce runoff and erosion. One company is involved in a project jointly planned with the Southwest Florida Water Management District for the creation of a water reservoir for flood control, water conservation, and recreation. In order to alleviate a future water shortage in the area, farsighted planning of this nature is valuable. Close cooperation is needed between industry and planning agencies on all levels to keep to a minimum conflicts that may arise from water use. One of the serious implications that could arise from a water shortage would be a productive cutback at a time when the demand for fertilizer materials may be critical.

There have been cases where phosphate reserves have been lost due to various regulations, but on the other hand, special ordinances have been passed to permit mining in areas where it was previously not allowed. In an area where known valuable mineral resources occur, it is necessary for all facts to be weighed carefully. If the land has valuable mineral resources, it can be mined and reclaimed for other uses.

Clear and reasonable zoning laws should be worked out with county governments to the benefit of the community and the industry. Zoning should impose fair controls and should identify mineral reosurce lands and consider the maximum use for these areas in zoning regulations. Close cooperation with industry and government, and public awareness of mineral resource problems and potential conflicts are necessary. We would like to point out to all planners that our mineral resources must be wisely conserved and the mineral policies we persue must be farsighted, planned with thought, and based on fact. 
APPENDIX A 



\section{POLICE POWERS}

\section{Article II. Mining Operations.}

Sec. 20-7. Declaration of municipal policy concerning mining operations within the city.

(a) The city commissioners of the city hereby find and determine that in mining or making of other permanent excavations of any kind or nature without supervision or prior plans and specifications, the person performing acts of such mining, or other permanent excavation, excavate and leave large, irregular holes in the land where the mining operations are carried on, and also that the person or company doing the mining, or permanent excavating, pile up and leave unsightly piles of earth; that lands so mined or excavated, without supervision or proper plans and specifications, and left worthless for any purpose, and that water collects and settles in holes in the ground where the mining or permanent excavations are made, and that such water stagnates and breeds mosquitoes; that such mining or excavating without supervision and proper plans and specifications, within the limits of the city would create unslightly and unsanitary conditions and be a public nuisance, and make it impossible to develop for building purposes or for any other useful purpose the land so mined or excavated.

(b) It is hereby declared the policy of the city, by and through its city commission, to protect the city and its inhabitants from the conditions hereinabove stated and to preserve those lands now being used for residential, business, pleasure and recreation purposes, and to foster creation of new, suitable and desirable locations for residential, business, pleasure and recreation within the city upon lands not now used for such purposes. (Ord. No. 324-A, $\oint$ 1, 5-6-53.) Statutes.

State law reference.-For general state law regarding conservation, see ch. 377, Florida

\section{BARTOW CODE}

Sec. 20-8. Commission to promulgate rules and regulations concerning same.

Mining operations, including the recovery of gas, oil or sulphur, or the making of other permanent excavations of any kind, is prohibited within the City of Bartow unless permit therefor is secured by the applicant from the City of 
Bartow. Rules and regulations may be promulgated by the city commission from time to time governing such operations. The exact plans and specifications of the proposed mining or excavating showing the manner in which the land will be left after said mining or excavating operation shall be carried out, shall be submitted by the applicant to the city commission for its approval by resolution prior to the visible commencement of such operation. If said plans and specifications are so approved, the applicant, before receiving a permit to commence said operation, shall give to the city in an amount to be fixed by the city manager a performance bond, or other security acceptable to the city manager, securing and guaranteeing the carrying out of said plans and specifications. Violation of any of the provisions or prohibitions of this article, or the violation of any rules and regulations promulgated under the authority of this article, is hereby declared unlawful, and any person so violating this article, or said rules and regulations, shall be punished as provided by law. (Ord. No. 330-A, $\oint 1$, 8-17-53; Ord. No. 466-A, $\oint 1,1-7-58$.)

Amendment note.-Ord. No. 466-A enacted on January 7, 1958, amended $\oint 20-8$ to read as hereinabove set out. This amendment reworded the section added the provision prohibiting mining within the city without a permit clarified the provisions requiring a performance bond and added the penalty clause. 
APPENDIX B 



\section{RESOLUTION NO. 793-R}

WHEREAS, under the provisions of Section 20-8 of the Code of Ordinances of the City of Bartow, the city commission is authorized to promulgate reasonable rules and regulations pertaining to mining or excavating of any kind or nature whatsoever inside the city limits; and

WHEREAS, the city commission deems it advisable and appropriate to adopt rules and regulations under the authority of said article;

NOW, THEREFORE, BE IT RESOLVED BY THE CITY COMMISSION OF THE CITY OF BARTOW:

1. The following regulations for mining or excavating within the city limits of Bartow be and the same hereby are adopted under the provisions of Section 20-8 of the Code of Ordinances of the City of Bartow, to-wit:

“(a) All mining, or excavating, of any kind or nature whatsoever, inside the city limits of the City of Bartow, shall be subject to the following general regulations, unless otherwise herein specifically provided:

(1) No structures or machinery for the recovery, processing or treating of any minerals, mined or produced inside the city limits of Bartow, shall be erected or operated inside the city limits; provided, that this shall not apply to structures or machinery ordinarily and necessarily used in the extracting or removing of such minerals from the ground for processing or treating.

(2) The use of explosives in mining or excavating shall be in strict accordance with the ordinances of the City in force at the time of their use, and such reasonable rules and regulations as may be promulgated by the City Manager to supplement or implement such ordinances.

(3) Any mining or excavating shall be carried on in such a manner as to prevent injury to the person, health and property of the inhabitants of this City.

(4) All lands mined or excavated shall be restored to a suitable condition for use as residential, commercial or industrial building sites, as may be authorized by the City Commission, and in such condition as to require no additional grading or filling, except the normal grading and filling in connection with developing such areas in this city.

(5) Any lakes, ponds, pools or lagoons that may be authorized by the City Commission, in connection with restoring the mined or excavated lands, shall be so constructed as to present a minimum of danger to the person, health and property of the inhabitants of this city.

(6) The materials and methods used in restoring the mined or excavated land, shall be such as to leave them in suitable condition for development as residential, commercial or industrial areas, as authorized by the City Commission. 
(7)All natural and artificial drains shall be restored to their original location and condition prior to the mining or excavating, unless otherwise authorized by the City Commission, and appropriate measures shall be taken during such mining or excavating to prevent any injury or damage from obstructing or changing the course of the waters running through the same.

(b) These regulations shall not apply to temporary excavations covering not more than four feet in width, and six feet in depth, not to borrow pits or other excavations that may be opened on lands that are to be mined, nor where such pits or excavations are designated by the City Commission as places to be refilled and restored by the landfill method of garbage disposal, not to excavations in connection with the construction of residences, nor to the maintenance of natural or artificial drains.

(c) The word 'person' when used in this resolution shall include natural persons, joint adventures, limited and general partnerships, common law trusts, and corporations.

(d) Before beginning any mining or excavating inside the city limits of the City, the owner of the lands upon which the mining or excavation is to be performed, and the persons under whose authority, direction, management or supervision the work of mining or excavating is to be carried on, and the persons for whose use and benefit the mining or excavation is to be done, shall obtain a permit therefor as hereinafter provided.

(e) Application for such permit shall be filed in writing with the City Manager, which application shall be accompanied by twelve legible copies of complete plans and specifications for such mining or excavating operations.

(f) Such plans and specifications shall include a map or plat, prepared and certified by a licensed civil engineer, drawn to scale, and adequately tied to known government land corners, or known recognized land monuments in the vicinity. The following information relative to the proposed mining or excavating operations shall be set forth upon said map or plat;

(1) The location of the lands upon which the mining or excavating is to be done.

(2) The area to be mined or excavated.

(3) The location of all existing or proposed streets, roads, sidewalks, electric transmission lines, telephone and telegraph lines, including cables above or underground, canals, drainage ditches, natural streams or drains, water mains, gas mains, sanitary and storm sewers, railroads, and any other facilities of like nature to these herein specifically set forth, or easements therefor, and any structures of any kind or nature, upon the lands involved in the proposed mining or exacavating operations, or in such proximity thereto as to the affected thereby. 
(4) All courtesy strips that will be set up and observed in the minimg or excavating operations.

(5) All other data which is coustomarily shown on like maps or plats, used in mining or excavating operations.

(g) Such plans and specifications shall also include topographical maps or plats, prepared and certified by a licensed civil engineer, showing: level.

(1) Contour lines at intervals of one foot, with their elevation above sea

(2) Cross sections at 100 foot intervals of the area to be mined or excavated.

(3) Contour lines of the mined area after restoration, at intervals of one foot, with their elevation above sea level.

(4) Cross sections at 100 foot intervals of the mined or excavated area after restoration.

(h) Such plans and specifications shall also set forth the following information relative to such mining or excavating operations:

(1) The approximate date upon which the mining or excavating operation will be commenced.

(2) The general methods which will be used in prosecuting the work, including the methods of preparing the site; disposal trees, shrubs and debris upon the land, removal of overburden and matrix, handling interference with the natural drainage of, the through the lands; and the use of the mined areas for settling purposes.

(3) The height and width of dams used in connection with the mining or excavating operations, and the materials and methods to be used in their construction.

(4) The method or methods to be used in restoring the mined or excavated areas, and the amount of earth required to fill up the mined or excavated areas to the required level.

(5) The condition to which the mined or excavated area is to be restored.

(6) The load bearing strength of the soil in the restored mined or excavated areas, which shall be of sufficent compaction for use as residential, commercial or industrial building sites.

(7) The date when the mining or excavating will be completed and the land restored to a useable condition, which shall be not more than five years from the date upon which the permit is issued.

(i) The City Manager shall present said plans and specifications to the City Commission, at regular meeting of the Commission, and the Commission shall approve or disapprove them not sooner than its next regular session, not later than its second regular session; provided, that if the City Commission shall 
disapprove the plans and specifications, it shall set forth in writing what changes must be made in such plans and specifications to secure their approval. Copies of the objections to the plans and specifications, and of the required changes, shall be furnished the applicants for the permit, but not more than 12 copies need be furnished.

(j) If the plans and specifications are amended to meet the requirements of the City Commission, they shall be approved at the regular meeting of the City Commission following the delivery of 12 copies thereof to the City Manager.

(k) It shall be the duty of the City Manager to deliver to each of the City Commissioners and the City Attorney one complete copy of the original plans and specifications at least five days prior to the meeting at which they are to be presented, and also one complete copy of any amended plans and specifications to said persons, at least two days before the meeting at which they are to be finally approved.

(1) The City Commission shall require the persons applying for the permit to give bond or security, in an amount and form to be prescribed and fixed by the City Manager in each case, to insure the performance of the mining or excavating operation in strict accordance with the approved plans and specifications; provided, that the City Manager may waive the bond or security, if the excavation will not involve more than forty thousand square feet in area and a depth of ten feet, and the persons applying for the permit are financially responsible for any damages arising from their failure to perform the work in strict accordance with the plans and specifications.

(m) When the plans and specifications are approved by the City Commission, and the bond or security required is posted and approved, the City Manager shall issue a permit for the proposed mining or excavating operation, and no permit therefor shall be issued by him until that time, except in the case hereinafter provided.

(n) When the excavating, for other than mining purposes, does not exceed more than four thousand feet in area, and a depth of not more than ten feet, the City Manager may, if he is satisfied with the plans and specifications, issue a permit for said excavating without the approval of the City Commission, but he shall report the issuance of the permit to the City Commission at its next regular meeting. 
(o) The City Engineer, if a licensed civil engineer, or some licensed civil engineer appointed by the City Manager, and confirmed by the City Commission, shall inspect the mining or excavating operations at such intervals as may be necessary to insure that it is being carried on in accordance with the plans and specifications, and thence shall be a reasonable charge made by the City for such inspection, but not to exceed $\$ 50.00$ per week.

2 . The rules and regulations above adopted shall be effective immediately.

PASSED IN REGULAR SESSION ON DECEMBER 16, 1957.

J.B. Crum

J.B. Crum, Mayor

Attest:

Charles A. Richardson

Charles A. Richardson, City Clerk 


\section{RESOLUTION NO. 837-R}

WHEREAS, under the provisions of Section 20-8 of the Code of Ordinances of the City of Bartow, the City Commission is authorized to promulgate reasonable rules and regulations pertaining to mining or excavating of any kind or nature whatever in the City Limits of the City of Bartow; and

WHEREAS, the City Commission has heretofore on December 16, 1957 passed in regular session Resolution No. 793-R setting forth regulations for mining or excavating within the City Limits of the City of Bartow as provided for under the provisions of Section 20-8 of the Code of Ordinances of the City of Bartow; and

WHEREAS, the City Commission deems it advisable and appropriate and in the best interest of the City of Bartow to make certain changes and amendments in Resolution No.793-R,

NOW, THEREFORE, BE IT RESOLVED BY THE CITY COMMISSION OF THE CITY OF BARTOW:

I. The following changes in Resolution No. 793-R regulating mining or excavating in the City Limits of Bartow and heretofore enacted on December 15,1957 , be and the same hereby are adopted under the provisions of Section 20-8 of the Code of Ordinances of the City of Bartow, to-wit:

(1) Section (h) (6) is hereby amended as follows:

(6) Whether or not the load bearing strength of the soil in the restored mined or excavated area shall be of sufficient compaction for use as residential, commercial or industrial building sites.

(2) Section (h) (7) shall be amended as follows:

(7) The time when the mining or excavating will be completed and the land restored to a useable condition shall not be more than 5 years from the date from which the permit is issued. 
II. The rules and regulations and changes above adopted shall be effective immediately.

PASSED IN SPECIAL SESSION NOVEMBER 19, 1959.

/s/ W. E. Blount, Jr.

W. E. Blount, Jr., as Mayor

\section{ATTEST:}

/s/ C. A. Richardson

C. A. Richardson, as City Clerk 

APPENDIX C 



\section{PERMISSION TO MINE WITHIN THE CITY OF BARTOW}

Permission is hereby granted to Armour Chemical Company, Bartow, Florida to mine those certain properties in the City of Bartow, Florida described in attached proposal in strict accordance with the terms set forth in said proposal as approved by the City Commission, December 21, 1959. Armour Agricultural Chemical Company's compliance with the terms of said proposal being assured by posting bond in the amount of $\$ 10,000$.

This is the proposed mining plan Armour submitted to the City of Bartow for mining or excavating inside the city limits of Bartow, Florida:

"In order to obtain approval in principal for mining of phosphate matrix within the city limits, the following is hereby submitted: (item numbers relate to sections and subsections or resolution No. $793-\mathrm{R}$ past December $16,1957$. )

A. (1) All powerlines, pipelines and operation machinery placed on a temporary basis will be moved from the premises when mining in the City, and pumping has been completed.

(2) No explosives will be used except in case of an extraordinary development that may require the use thereof for work related to land restoration to be done by others.

(3) Areas will be mined with due regard for adjacent properties, streets, and roadways. Drainage will be provided as mining progresses.

(4) Land restoration as currently planned is subject to acquiring adjacent properties. The property is not a joint venture but one that requires cooperation of the several parties involved, whereby phosphate rock may be recovered rather than totally lost from the Florida reserve. Valuable land will be restored and an area of approximately 75 acres converted from a swampland to improved property. The overall full program may be stated as follows:

(a) Acquire Stewart and Clark properties section 6 fronting on highway 60 at Woodlawn Avenue.

(b) Acquire Clark property section 7 adjacent to City cemetery.

(c) Acquire 35-acre Exchange National Bank of Tampa, Trustee property. Section 7 west of City cemetery. 
(d) The Company has option to acquire the foregoing properties and it is anticipated that the purchases thereof will be started within 10 days after the City issues permit to mine hereunder.

(e) Mine the areas in manner indicated on plat 3. Armour will pump sand tailings into pits as necessary to result in an elevation of 110 to 113 feet when overburden rows are graded by others, except in those areas designated as lakes and drainage creeks as indicated on plat 4. Restoration of the lands to final grade in Areas A, B, and D on plat 1 shall be completed by Richard Clark of Bartow. Restoration of lands to final grade in Area $C$ shall be completed by the present owners agent or contractor.

(5) Lakes, pools or lagoons in connection with the restoration program will be located on private property. An approximate lake depth, as shown on plat, may be a maximum of 30 feet. Concrete and sand tailings will be used to plug subterranean drainage faults when practical.

(6) Recent tests by the Pittsburgh Testing Laboratory indicate that if sand tailings are pumped into an area and water level is not excessive, good compaction will result. Overburden rows are generally well compacted.

(a) The overburden will be placed in the normal windrow manner, parallel to the mining cuts as indicated wherein. These overburden rows will not contain trees and underbrush and they will have already been burned prior to mining. Sand will be pumped between these windrows in a hydraulic slurry. It is indicated this property can be restored to some practical use by taking these necessary steps through this mining operation. However, the final determinition would have to come after the operation is complete and tests made at that time. It has been determined that if the sand is pumped in, and the water promptly removed, good density is obtained. Plans call for the operation of a pump at the bottom of the mining cuts when necessary to remove water. Sandfill will be brought to the predetermined elevation and then covered with overburden from the windrows to obtain final grade.

(7) Caney Creek and other natural drainages cannot be rerouted from their original locations. Class 4 indicates the approximate final location of McKinley Creek and drainage in this area park section. 
B. The proposed project is not a temporary excavation job; it represents a major project and should result in a decided improvement of the land at the west limits of the city.

C. The exact nature of the restoration portion of this project has not been completed in detail. Armour and Company, and Illinois Corporation, needs assurance that mining the above area referred to will be permitted by the City.

D. The purpose of this outlined procedure is to lay the ground work for obtaining the required city permit.

E. Application for the permit is hereby made in writing and directed to the City Manager. Twelve copies of the application and general layout plans are attached.

F. The plans, which have been prepared by a graduate civil engineer certified by a licensed civil engineer, tie the property lines to known land markers.

H. Plans and specifications cannot be fully detailed until adjacent lands are acquired. Adjacent lands will not be acquired by Armour unless a permit to mine is issued by the City. A tentative program may proceed as follows: No. 1. Mining shall start about January 15, 1960 adjacent to Woodlawn Avenue after clearing the drainage of the areas. Starting time will depend upon the issuance of permit to mine. No. 2. Surface areas will be cleared as mining progresses. The trees and undergrowth will be burned. Overburden will be piled in standard mining pattern. rows. Matrix will be pumped to Armour's recovery plant west of Bartow. Natural drainage will be directed as necessary through the mining period. The mined out land will be used to accomodate tailings sand pumped into the pits to the extent necessary to properly grade the area compatible with surrounding lands but not to exceed an elevation of 150 feet. No. 3. Low dykes of earth construction 6 to 8 feet high may be required at intervals to divert the flow of the sand water pipeline output. Excess waters will be directed in McKinley Creek under control conditions to prevent flooding of low areas. The amount of sandfill and overburden material required to restore the mined out areas will depend upon the land required.

(6) There can be no guarantee of 3,000 pounds per square foot of load bearing strength. Compaction will be practical within reason by controlling water depths while filling with sand tailings. Some additional compactior. may result through operation of grading machinery in the final leveling work. Materials and methods used in restoring mined or excavated land shall be such as to leave them in a suitable condition for 
development as residential, commercial or industrial areas, and is hereby understood and agreed that no building will be erected on this reclaimed land until adequate tests have been made b; a qualified testing laboratory. In each instance all information regarding the soil stability of a given lot or portion of reclaimed land shall accompany any application for building permit, to erect, move or add to a building on reclaimed land.

(7) Mining will proceed from the eastern part of the land, that is, adjacent to Woodlawn Avenue, with mining cuts in a north and south direction working westwardly to the City limits and will extend over approximately 15 months. It appears that approximately 3 cuts have been made. The dragline is about 900 feet from Woodlawn Avenue and it would be possible to begin pumping tailings into the mined out area. Thus, sandfill could begin about 6 months after mining has begun. Restoration of land will require approximately 5 years. Request is hereby made to present this matter." 




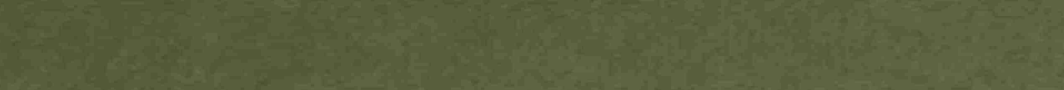

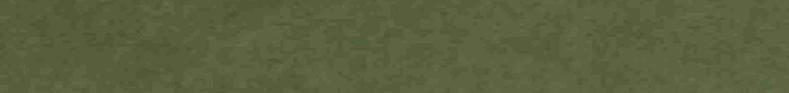

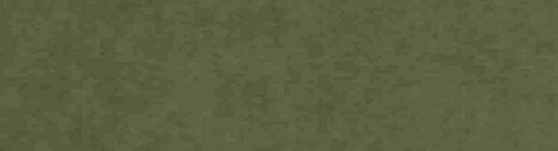

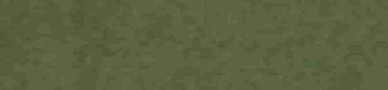

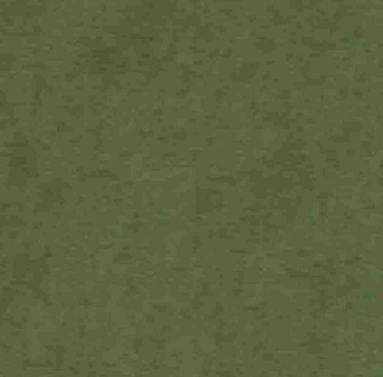

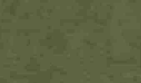

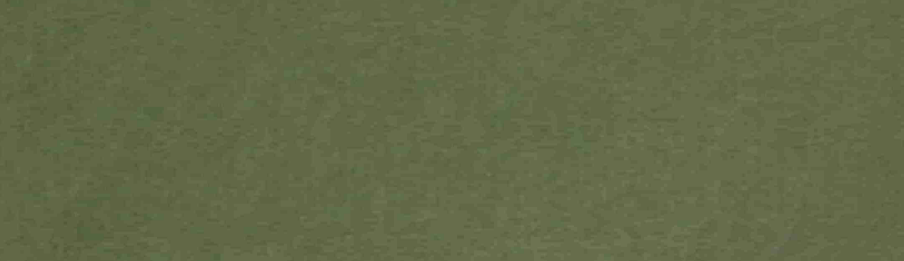

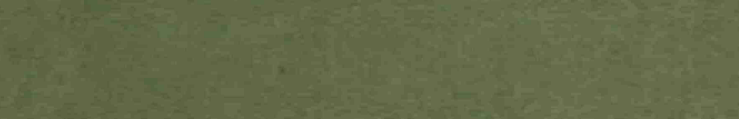

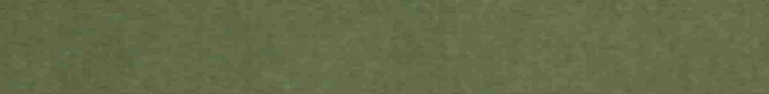

Fis

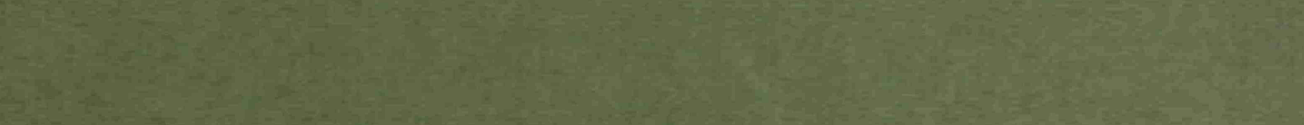

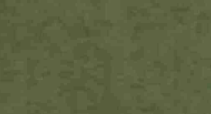

$x^{2}+x^{2}$

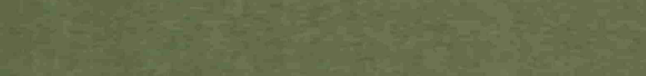

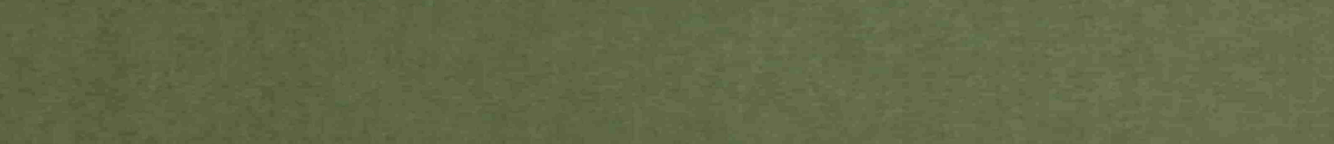

1.

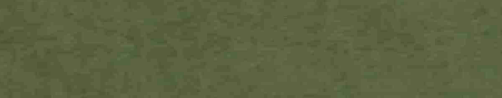

글 3

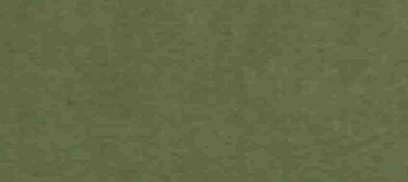


